\title{
EXCURSION TO BROCKLEY, BROMLEY PARK AND BECKENHAM.
}

SATURDAy, JULY I6TH, I92I.

Report by C. N. Bromehead, Director of the Excursion.

Plate 4.

A PARTY of about 20 assembled at New Cross Station and made their way to Brockley Brickworks. The greater part of the material worked here is that dumped on the natural surface when the railway cutting was made; some of it may even date from the digging of the old Croydon Canal, whose course the railway follows for considerable distances. Below this dump material shallow sections revealed a part of the Woolwich Series, with a fine development of the freshwater limestone. The rock is an impure argillaceous limestone, resembling the London Clay septaria; a horizontal parting is locally crowded with specimens of Paludina lenta, while Unio, Pitharella and Hydrobia occur sparingly. The main object of the excursion was, however, to view the remarkable structure revealed by the cleaning of the western side of the cutting, opposite the brickworks and a short distance north of Brockley Station. The Director remarked that the general sequence of beds in the cutting had been described many times. The upper part was London Clay, with a pebbly Basement Bed 9 to 18 inches thick; below this the Woolwich Beds consisted of a few feet of sand resting on shelly clays with Cyrena divided into upper and lower parts, about 3 and 6 feet thick respectively, by the freshwater limestone. The earlier accounts have been summarised by Mr. Whitaker,* while the description in the South London Sheet Memoir includes notes from accounts published when the line was widened. The part now cleaned had apparently never been uncovered since the cutting was first made and showed two remarkable folds well brought out by the varying components of the Woolwich Beds. In the photograph (Plate 4), the Director is pointing to the limestone band in the trough between the two wave-like folds. On the extreme left this bed is vertical on the steeper side of a fold which brings up the sandy Bottom Bed, while to the right the beds are actually overfolded.

The Director expressed the opinion that the folds were superficial rather than tectonic. Behind the houses was the high ground of Hatcham, a London Clay hill. Such masses of London Clay were peculiarly liable to slip in the direction of the dip, as could be seen on Knight's Hill and elsewhere. Such movements had no visible effects on the homogeneous and plastic

- "Geology of London" (Mem. Geol. Surv.), Vol. i., 1889, pp. 156, I57. 
London Clay, when revealed in section, unless a hard band, such as a layer of septaria, was present. At Brockley the hard thin band of limestone in the Woolwich Beds revealed the folds produced by the drag of the moving mass of clay above, and the varying colours and composition of the beds rendered the structures conspicuous. The dip was to the south-east, towards the fault, which crossed the railway a little to the south of Brockley Station, and the movement had been in that direction. The President agreed that the folds might be largely superficial, but thought that the neighbourhood of the fault might also be partly responsible.

The party then walked over Hilly Fields to Ladywell and took the tram to Southend. Two new pits on the east side of the road to Bromley were then visited; the lower showed nothing but sand, the upper flint-pebbles in a sandy matrix. The Director maintained that the two were, owing to the northerly dip, on approximately the same horizon in the Blackheath Beds, the difference being due to lateral changes. Such changes were by no means unknown in these beds; an instance at Park Langley is described in the South London Memoir, where two pits, Ioo yards apart, show respectively 20 feet of grey and yellow sand, and I2 feet of pebbles. In the upper pit blocks of conglomerate were noted, the cement being calcareous and derived from the partial destruction of shells.

A little further up the hill an older pit again showed the normal pebble-beds, while on the walk through Bromley Park road cuttings showed intercalated beds of clean sand several feet in thickness. On Crab Hill, just above Ravensbourne Station, a halt was made at a somewhat overgrown pit, showing London Clay resting on Blackheath Beds, with large masses of conglomerate and many fossils. The Director remarked that at Brockley the London Clay had been seen resting directly on Woolwich Beds ; near Bromley as much as 80 feet of Blackheath Beds intervened, and at Beckenham about 50 feet.

Tea was taken by a somewhat diminished party at Beckenham close to the spot where Mr. R. W. Pocock obtained specimens of Ostrea bellovacina with the ligaments preserved from a temporary excavation in Woolwich Beds.* 


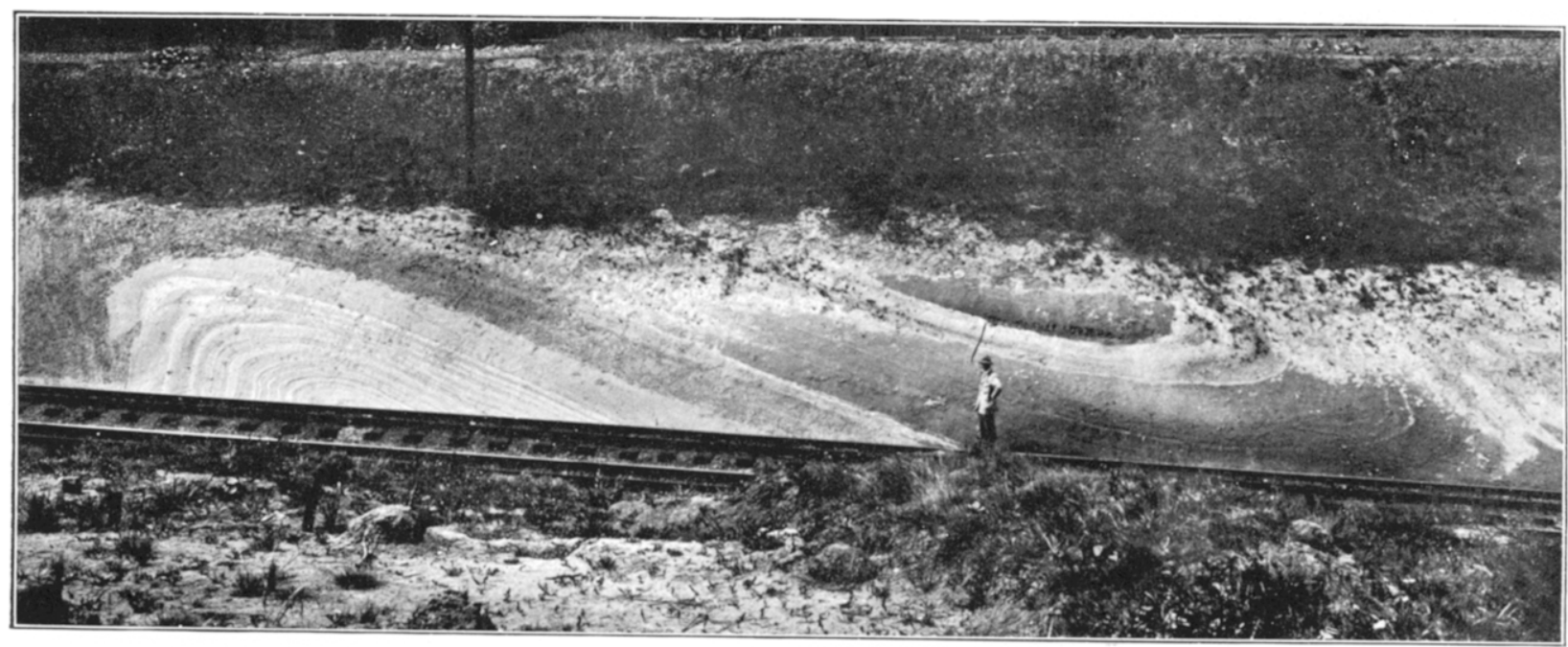

Photo by H.M. Geological Survey. Folding in the Woolwich Beds between Brockley and New Cross. 